Article

\title{
Chemical Profiling and Cholinesterase Inhibitory Activity of Five Phaedranassa Herb. (Amaryllidaceae) Species from Ecuador
}

\author{
Raúl Moreno ${ }^{1} \mathbb{D}$, Luciana R. Tallini ${ }^{1,2}{ }^{,}$Cristina Salazar ${ }^{3}$, Edison H. Osorio ${ }^{4}{ }^{\oplus}$, Evelin Montero ${ }^{3}$, \\ Jaume Bastida ${ }^{1}$, Nora H. Oleas ${ }^{5, *}$ and Karen Acosta León ${ }^{3}$ \\ 1 Group of Natural Products, Faculty of Pharmacy, University of Barcelona, Av. Joan XXIII, 27-31, \\ 08028 Barcelona, Spain; raul.orlando.mm@gmail.com (R.M.); lucianatallini@gmail.com (L.R.T.); \\ jaumebastida@ub.edu (J.B.) \\ 2 Faculty of Pharmacy, Federal University of Rio Grande do Sul, Av. Ipiranga 2752, \\ Porto Alegre RS 90610-000, Brazil \\ 3 Grupo de Investigación de Productos Naturales y Farmacia, Facultad de Ciencias, Escuela Superior \\ Politécnica del Chimborazo, Panamericana Sur km 1 1/2, Riobamba EC060155, Ecuador; \\ criss93danny@gmail.com (C.S.); eve_montero15@hotmail.com (E.M.); karen.acosta.leon@gmail.com (K.A.L.) \\ 4 Facultad de Ciencias Naturales y Matemáticas, Universidad de Ibagué, Carrera 22 Calle 67, \\ Ibagué 730001, Colombia; edison.osorio@gmail.com \\ 5 Centro de Investigación de la Biodiversidad y Cambio Climático (BioCamb) e Ingeniería en Biodiversidad \\ y Recursos Genéticos, Facultad de Ciencias de Medio Ambiente, Universidad Tecnológica Indoamérica, \\ Machala y Sabanilla, Quito EC170301, Ecuador \\ * Correspondence: noraoleas@uti.edu.ec
}

Academic Editor: John C. D'Auria

Received: 3 March 2020; Accepted: 21 April 2020; Published: 30 April 2020

check for updates

\begin{abstract}
It is estimated that 50 million people in the world live with dementia, $60-70 \%$ of whom suffer from Alzheimer's disease (AD). Different factors are involved in the development of AD, including a reduction in the cholinergic neurotransmission level. The Amaryllidaceae plant family contains an exclusive, large, and still understudied alkaloid group characterized by a singular skeleton arrangement and a broad spectrum of biological activities. The chemistry and biodiversity of Ecuadorian representatives of the Phaedranassa genus (Amaryllidaceae) have not been widely studied. In this work, five Ecuadorian Phaedranassa species were examined in vitro for their activity towards the enzymes acetyl- (AChE) and butyrylcholinesterase (BuChE), and the alkaloid profile of bulb extracts was analyzed by GC-MS. The species Phaedranassa cuencana and Phaedranassa dubia showed the most AChE and BuChE inhibitory activity, respectively. To obtain insight into the potential role of the identified alkaloids in these inhibitory effects, docking experiments were carried out, and cantabricine showed in silico inhibitory activity against both cholinesterase structures. Our results show that Amaryllidaceae species from Ecuador are a potential source of new drugs for the palliative treatment of AD.
\end{abstract}

Keywords: alkaloids; Amaryllidaceae; cholinesterases; GC-MS; molecular docking; Phaedranassa

\section{Introduction}

Natural products represent an interesting source of bioactive compounds and have led, directly or indirectly, to the development of about two thirds of the new medicines approved in recent years [1]. Plants are widely used in folk medicine, and plant extracts have long been tested in screening programs in pharmaceutical companies and university institutes as sources of new commercially viable 
drugs [2]. Alkaloids—secondary metabolites found mainly in plants—have an important role in drug development because of their structural diversity [1,3,4].

The alkaloids present in the Amaryllidaceae family have attracted considerable attention because of their unique and diversified structures, as well as their biological potential [5]. Phaedranassa Herb. is a small Amaryllidaceae genus of ten species, most of them endemic to Ecuador [6]. These species are found in specific localities restricted to dry valleys or wet slopes in the Andes over $1200 \mathrm{~m}$ [7]. Except for P. dubia, the seven endemic species from Ecuador are either endangered or vulnerable to extinction under IUCN criteria [8]. Studies have shown that the genetic structure of the species has been influenced by relatively recent events such as volcanism and urban development $[9,10]$.

About 50 million people live with dementia in the world today, and Alzheimer's disease (AD) is one of the most usual forms of this pathology [11]. Different factors seem to be involved in the development of $\mathrm{AD}$, including a reduction in the cholinergic neurotransmission level [12,13]. At the beginning of this century, the Amaryllidaceae alkaloid galanthamine was approved by the Food and Drug Administration (FDA) for the clinical treatment of AD because of its acetylcholinesterase inhibitory activity [14]. As high cost and low yields render galanthamine synthesis inviable, it is obtained by pharmaceutical companies from natural sources such as Galanthus nivalis, Leucojum aestivum, Lycoris radiata, and several species of Narcissus [15].

Considering the Amaryllidaceae alkaloid potential in AD therapy, the aim of this study was to identify the alkaloid content of five different Phaedranassa species collected in Ecuador (Figure 1) and to analyze the anticholinesterase activity of these samples. The alkaloid profiling of P. cinerea, P. cuencana, P. dubia, P. glauciflora, and P. tunguraguae was performed by gas chromatography coupled to mass spectrometry (GC-MS). The AD therapeutic potential of these species was evaluated by analyzing the $\mathrm{AChE}$ and BuChE inhibitory activity of each sample. Molecular docking studies were also carried out to investigate the binding affinity of the alkaloids identified in Phaedranassa species toward the active sites of AChE and BuChE.

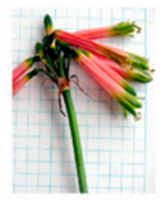

A

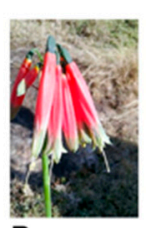

B

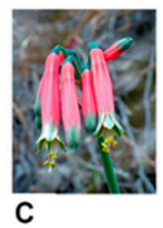

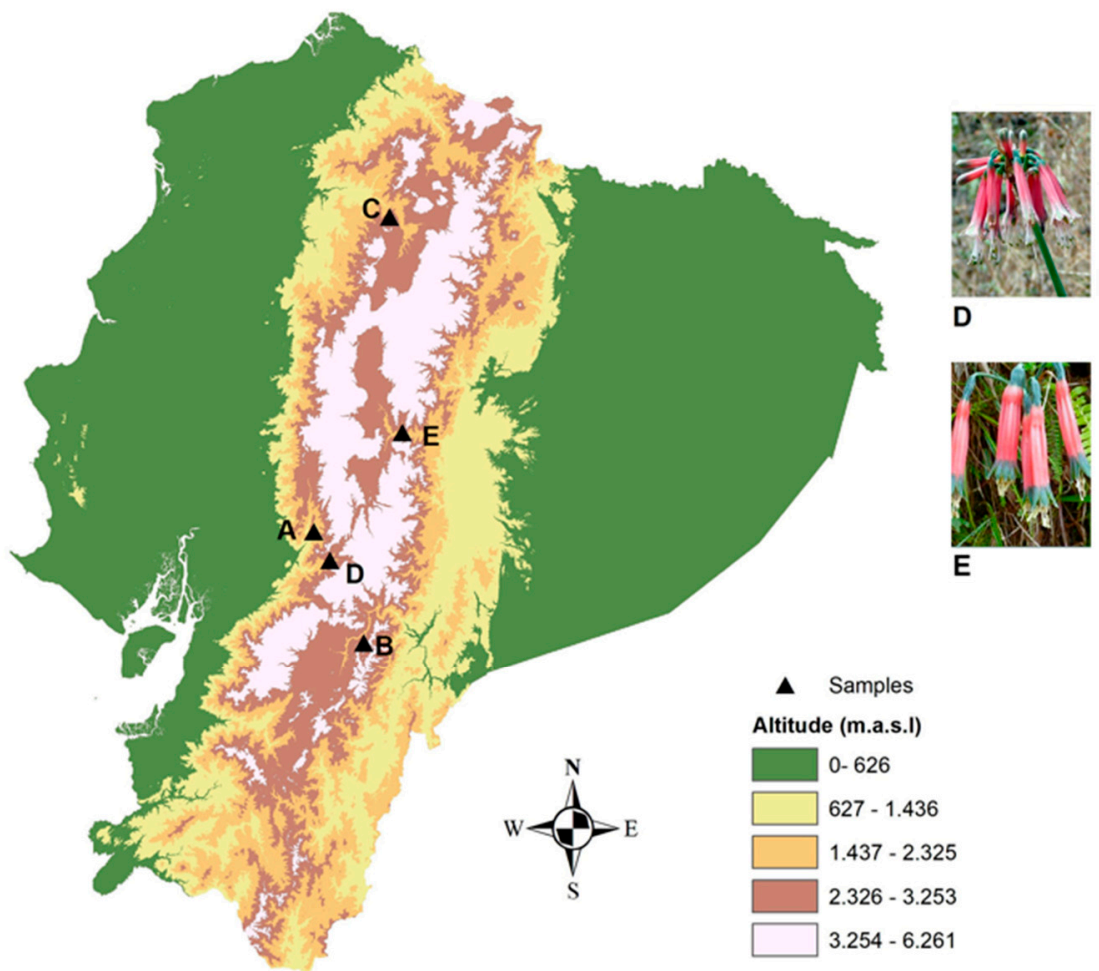

Figure 1. Distribution of Phaedranassa Herb. species in Ecuador. (A): P. cinerea; (B): P. cuencana; (C): P. dubia; (D): P. glauciflora; (E): P. tunguraguae. 


\section{Results and Discussion}

\subsection{Alkaloids Identified by GC-MS}

The identified alkaloids and their structures are represented in Table 1 and Figure 2, respectively. The alkaloids present in the analyzed samples were identified by comparing their GC-MS spectra and Kovats retention index (RI) values with those of authentic Amaryllidaceae alkaloids previously isolated and identified by spectrometric methods (NMR, UV, CD, IR, MS) in the Natural Products Laboratory of Barcelona University, the NIST 05 Database, or literature data.

Table 1. Alkaloids identified in different species of Phaedranassa Herb. from Ecuador by GC-MS. Values are expressed as $\mathrm{mg} \mathrm{GAL} \cdot \mathrm{g}^{-1} \mathrm{AE}$.

\begin{tabular}{|c|c|c|c|c|c|c|c|c|}
\hline Alkaloid & {$\left[\mathbf{M}^{+}\right]$} & B.P. & R.I. & $\mathbf{A} * \mathbf{a}$ & $\mathbf{B} * \mathbf{b}$ & $C * c$ & $D * d$ & $E * e$ \\
\hline Anhydrolycorine (1) & 251 & 250 & 2534.4 & - & 2.39 & 3.52 & 2.69 & - \\
\hline 11,12-Dehydroanhydrolycorine (3) & 249 & 248 & 2638.6 & - & 2.39 & 3.43 & 2.80 & - \\
\hline Galanthine (4) & 317 & 242 & 2730.1 & - & - & - & - & 5.36 \\
\hline 1-O-Acetyllycorine (5) & 329 & 226 & 2747.2 & - & 2.59 & - & 2.35 & - \\
\hline Sternbergine (8) & 331 & 228 & 2831.4 & - & - & - & 10.10 & 8.64 \\
\hline 2-Methoxypratosine (9) & 309 & 309 & 3084.0 & - & - & - & - & 2.50 \\
\hline Crinine/haemanthamine-type & & & & - & - & - & 6.34 & 7.70 \\
\hline 8-O-Demethylmaritidine (10) & 273 & 273 & 2532.2 & - & - & - & - & 3.81 \\
\hline Cantabricine (11) & 317 & 317 & 2639.9 & - & - & - & - & 3.89 \\
\hline Sanguinine (14) & 273 & 273 & 2403.1 & - & 18.85 & - & - & - \\
\hline$N$-Demethylgalanthamine (15) & 273 & 272 & 2428.3 & 5.51 & 2.65 & 8.64 & - & - \\
\hline$N$-Formylnorgalanthamine (16) & 301 & 301 & 2834.4 & 6.37 & - & - & - & - \\
\hline Mesembranone-type & & & & - & - & - & 5.15 & - \\
\hline 6-Epimesembranol (17) & 291 & 290 & 2379.7 & - & - & - & 2.90 & - \\
\hline Mesembrine (18) & 289 & 218 & 2396.5 & - & - & - & 2.25 & - \\
\hline Montanine-type & & & & 6.17 & - & - & - & - \\
\hline Pancratinine C (19) & 287 & 176 & 2622.2 & 6.17 & - & - & - & - \\
\hline Unidentified & & & & 17.22 & - & 2.40 & 11.76 & 27.54 \\
\hline Unknown (28) (lycorine type) $* g$ & $315 * f$ & 240 & 2805.7 & - & - & - & - & 2.26 \\
\hline Unknown (29) (lycorine type) $* g$ & $329 * f$ & 268 & 2873.2 & - & - & 2.40 & - & - \\
\hline Unknown (30) (lycorine type) $* g$ & $289 * f$ & 228 & 2873.9 & - & - & - & 2.81 & - \\
\hline Unknown (31) (homolycorine type) *g & $331 * f$ & 125 & 2928.3 & - & - & - & 2.35 & - \\
\hline Unknown (32) (lycorine type) *g & $374 * f$ & 284 & 2953.7 & - & - & - & - & 3.04 \\
\hline Unknown (33) (lycorine type) *g & $295 * f$ & 294 & 2963.1 & - & - & - & - & 4.43 \\
\hline Total & & & & 51.26 & 191.19 & 103.41 & 139.73 & 122.91 \\
\hline
\end{tabular}

*a A: P. cinerea; ${ }^{* \mathrm{~b}}$ B: P. cuencana; ${ }^{* \mathrm{c}}$ C: P. dubia; ${ }^{* \mathrm{~d}}$ D: P. glauciflora; ${ }^{* \mathrm{e}}$ E: P. tunguraguae; ${ }^{* \mathrm{f}}$ possible molecular ion peak; $* g$ proposed structure-type according to the fragmentation pattern. 


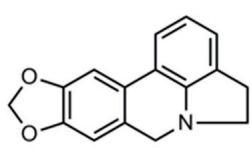

(1)<smiles>c1cc2c3c(c1)ccn3Cc1cc3c(cc1-2)OCO3</smiles>

(3)

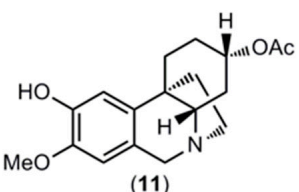<smiles>[R7]C1([R2])CC[C@@]2(c3ccc(OC)c(OC)c3)CCN[C@H]2C1</smiles>

(17) $\mathrm{R}_{1}=\mathrm{OH}, \mathrm{R}_{2}=\mathrm{H}$ (18) $R_{1}+R_{2}=O$

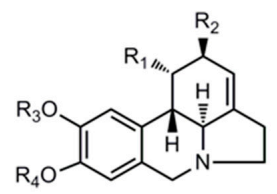

(2) $\mathrm{R}_{1}=\mathrm{OAc}, \mathrm{R}_{2}=\mathrm{H}, \mathrm{R}_{3}+\mathrm{R}_{4}=\mathrm{CH}_{2}$ (4) $\mathrm{R}_{1}=\mathrm{OH}, \mathrm{R}_{2}=\mathrm{OMe}, \mathrm{R}_{3}=\mathrm{R}_{4}=\mathrm{Me}$ (5) $\mathrm{R}_{1}=\mathrm{OAc}, \mathrm{R}_{2}=\mathrm{OH}, \mathrm{R}_{3}+\mathrm{R}_{4}=\mathrm{CH}_{2}$ (7) $\mathrm{R}_{1}=\mathrm{OH}, \mathrm{R}_{2}=\mathrm{OH}, \mathrm{R}_{3}+\mathrm{R}_{4}=\mathrm{CH}_{2}$ (8) $\mathrm{R}_{1}=\mathrm{OAc}, \mathrm{R}_{2}=\mathrm{OH}, \mathrm{R}_{3}=\mathrm{Me}, \mathrm{R}_{4}=\mathrm{H}$

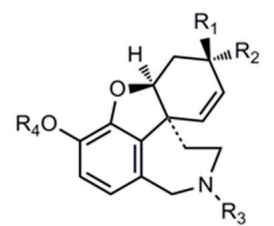

(13) $\mathrm{R}_{1}=\mathrm{OH}, \mathrm{R}_{2}=\mathrm{H}, \mathrm{R}_{3}=\mathrm{Me}, \mathrm{R}_{4}=\mathrm{Me}$ (14) $\mathrm{R}_{1}=\mathrm{OH}, \mathrm{R}_{2}=\mathrm{H}, \mathrm{R}_{3}=\mathrm{Me}, \mathrm{R}_{4}=\mathrm{H}$ (15) $\mathrm{R}_{1}=\mathrm{OH}, \mathrm{R}_{2}=\mathrm{H}, \mathrm{R}_{3}=\mathrm{H}, \mathrm{R}_{4}=\mathrm{Me}$ (16) $\mathrm{R}_{1}=\mathrm{OH}, \mathrm{R}_{2}=\mathrm{H}, \mathrm{R}_{3}=\mathrm{CHO}, \mathrm{R}_{4}=\mathrm{Me}$

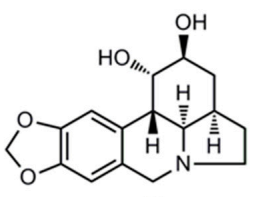

(6)<smiles></smiles>

(9)

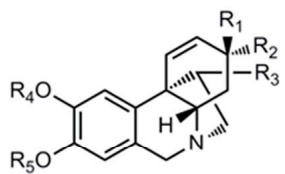

(10) $\mathrm{R}_{1}=\mathrm{OH}, \mathrm{R}_{2}=\mathrm{H}, \mathrm{R}_{3}=\mathrm{H}, \mathrm{R}_{4}=\mathrm{Me}, \mathrm{R}_{5}=\mathrm{H}$ (12) $\mathrm{R}_{1}=\mathrm{OMe}, \mathrm{R}_{2}=\mathrm{H}, \mathrm{R}_{3}=\mathrm{OH}, \mathrm{R}_{4}+\mathrm{R}_{5}=\mathrm{CH}_{2}$

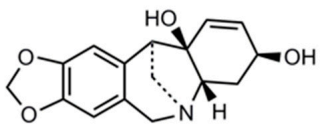

(19)

Figure 2. Alkaloids identified in Ecuadorian Phaedranassa Herb. by gas chromatography coupled to mass spectrometry (GC-MS).

Approximately $50 \%$ of the identified alkaloids were of the lycorine type and $15 \%$ of the crinine/haemanthamine type. About $85 \%$ corresponded to three different alkaloid types-lycorine, crinine/haemanthamine, and galanthamine-and the others were mesembranone- and montanine-type (Figure 3a). The number of alkaloids identified in the samples varied according to the species, ranging from ten in P. glauciflora (sample D) to four in P. cinerea (sample A) (Figure 3b).

All the alkaloids detected in P. cuencana (sample B) were identified (Table 1). The greatest number of unknown compounds (7) was found in P. tunguraguae (sample E) (Figure 3c). Overall, we were unable to identify about $40 \%$ of the compounds detected in the Phaedranassa species, but their structural type was proposed by their fragmentation patterns (Table 1). The high percent of unknown compounds in these samples suggests the genus may contain many new alkaloids. To determine the identity of the unknown structures, it will be necessary to isolate each compound by chromatographic methods and perform a detailed study using spectroscopic methods, such as nuclear magnetic resonance (NMR). In the current study, the quantity of Phaedranassa samples was insufficient for this step.

The highest alkaloid concentration was found in P. cuencana (sample B) and the lowest in P. cinerea (sample A) (191.19 and $51.26 \mathrm{mg} \mathrm{GAL} \cdot \mathrm{g}^{-1} \mathrm{AE}$, respectively). In about $80 \%$ of the samples, lycorine-type alkaloids predominated and were detected in all the species except $P$. cinerea (sample A). Galanthamine-type alkaloids were found in all the species, with the highest concentration in P. cuencana

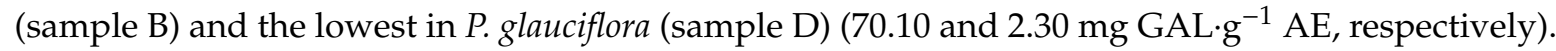
Alkaloids of the crinine/haemanthamine type were detected in $40 \%$ of the samples, with the highest

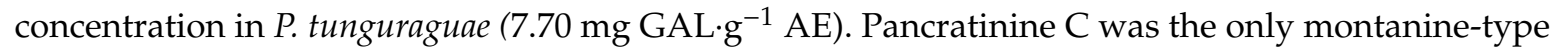
alkaloid identified, present in $P$. cinerea (sample A). Mesembrenone-type alkaloids were detected in low quantities in P. glauciflora ( $5.15 \mathrm{mg} \mathrm{GAL} \cdot \mathrm{g}^{-1} \mathrm{AE}$ ) (sample D). The highest content of unidentified alkaloids was detected in P. tunguraguae (sample E) (27.54 $\mathrm{mg} \mathrm{GAL}^{-1} \mathrm{AE}$ ), which had a high concentration of a compound showing an ion peak at $\mathrm{m} / \mathrm{z} 275\left[\mathrm{M}^{+}=275\right]$ (RI 2574.4) (8.87 $\mathrm{mg} \mathrm{GAL} \cdot \mathrm{g}^{-1}$ AE) (Table 1). 
(a)

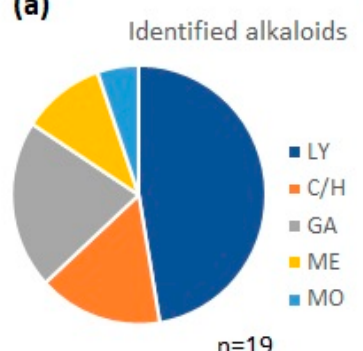

(b)

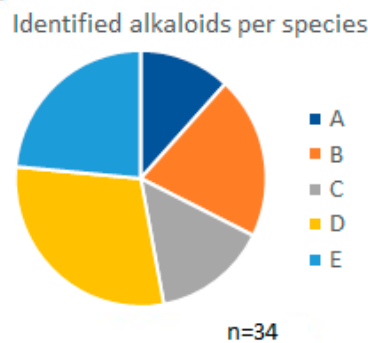

(c)

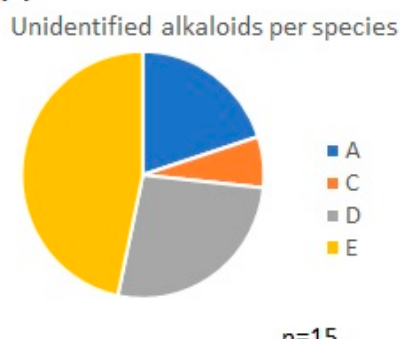

Figure 3. Graphical representation of the chemical profile of Phaedranassa Herb. species by GC-MS. (a) Distribution of alkaloids identified in all samples by type; (b) comparison of number of identified alkaloids among species; (c) comparison of number of unidentified alkaloids among species. LY: lycorine-type; C/H: crinine/haemanthamine-type; GA: galanthamine-type; ME: mesembranone-type; MO: montanine-type; A: P. cinerea; B: P. cuencana; C: P. dubia; D: P. glauciflora; E: P. tunguraguae.

A high diversity of lycorine-type alkaloids has also been reported in several Lycoris species collected in China, and a great variety of lycorine- and crinine/haemanthamine-type alkaloids have been recently described in different Rhodophiala species collected in Chile [16,17]. Previous research has identified phaedranamine, haemanthamine, pseudolycorine, ungeremine, zefbetaine, sanguinine, galanthamine, and epinorgalanthamine alkaloids in a Phaedranassa dubia sample collected in Colombia [18]. Moreover, one of the first chemical studies of Amaryllidaceae plants from Ecuador found twenty-two known and five unknown alkaloids in Stenomesson aurantiacum, which showed a high abundance of haemanthamine [19].

\subsection{AChE and BuChE Inhibitory Activities}

The alkaloid extracts from different species of Ecuadorian Phaedranassa Herb. were tested in vitro for $\mathrm{AChE}$ and BuChE inhibitory activities (Figure 4). Galanthamine, which was used as a control, presented $\mathrm{AChE}$ and $\mathrm{BuChE}$ inhibition with $\mathrm{IC}_{50}$ values of $0.33 \pm 0.02$ and $3.81 \pm 0.23 \mu \mathrm{g} \cdot \mathrm{mL}^{-1}$, respectively. All the evaluated alkaloid extracts were active against $\mathrm{AChE}$ and $\mathrm{BuChE}$, particularly those of P. cuencana (sample B), P. dubia (sample C), and P. tunguraguae (sample E). AChE inhibition was highest in $P$. cuencana (sample B) ( $\mathrm{IC}_{50}$ value: $0.88 \pm 0.11 \mu \mathrm{g} \cdot \mathrm{mL}^{-1}$ ), whereas the best activity against BuChE was observed in P. dubia (sample C) ( $\left(\mathrm{IC}_{50}\right.$ value: $\left.14.26 \pm 2.71 \mu \mathrm{g} \cdot \mathrm{mL}^{-1}\right)$. The high concentration of galanthamine-type alkaloids in P. cuencana (sample B) $\left(70.10 \mathrm{mg} \mathrm{GAL}^{-1}{ }^{-1} \mathrm{AE}\right.$ ) could explain its remarkable AChE inhibitory activity.

Galanthamine (13) has been described in different Amaryllidaceae genera-including Haemanthus, Lycoris, Hippeastrum, Hymenocallis, Narcissus, and Leucojum-and is obtained from natural sources by pharmaceutical companies $[12,20]$. Some researchers have reported that the alkaloid sanguinine (14) presents higher AChE inhibitory activity than galanthamine (13), but they also describe that galanthamine (13) can permeate the blood-brain barrier more effectively than sanguinine (14) [21]. Studies show that $11 \alpha$-hydroxy-O-methylleucotamine, another galanthamine-type alkaloid, has significant AChE inhibitory activity $\left(\mathrm{IC}_{50} 3.5 \mu \mathrm{M}\right)$, but no information about its capacity to permeate the blood-brain barrier has been reported [22].

\subsection{Molecular Docking}

The theoretical affinity of all the alkaloids identified in this study toward the active sites of AChE and BuChE together with values reported in the literature are listed in Table 2. The molecular docking results were analyzed for the different interactions between the alkaloids and the active site of the enzymes: hydrogen bonds, $\pi-\pi$ stacking, and anionic interactions. For $\mathrm{AChE}$ and $\mathrm{BuChE}$, the active site is in the center of the macromolecule, with the catalytic triad region containing residues Ser200, His440, and Glu327 for TcAChE proteins and His438, Ser198, and Glu325 for hBChE proteins [23-25]. 

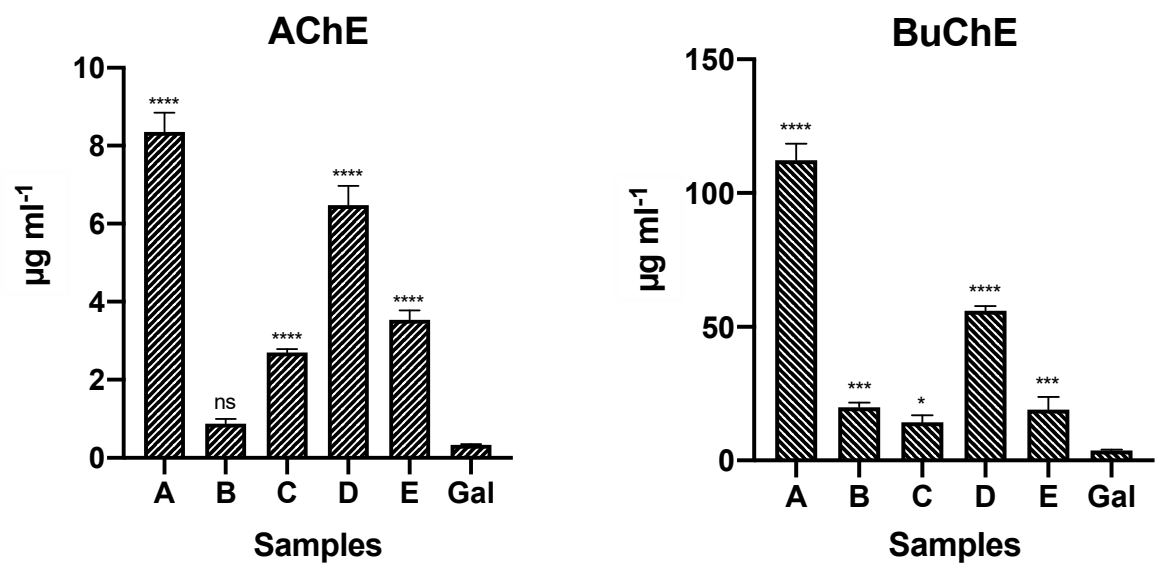

Figure 4. AChE and BuChE inhibitory activities of five different Phaedranassa Herb. species from Ecuador. Values are expressed as $\mathrm{IC}_{50}\left(\mu \mathrm{g} \cdot \mathrm{mL}^{-1}\right)$. A: P. cinerea; B: P. cuencana; C: P. dubia; D: P. glauciflora; E: $P$. tunguraguae; GAL: Galanthamine control. ${ }^{* * * *} p<0.0001,{ }^{* * *} p<0.001,{ }^{*} p<0.5$, and ns (not significant).

Table 2. Estimated binding free energy in molecular docking of alkaloids identified in extracts of

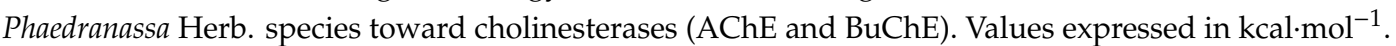

\begin{tabular}{|c|c|c|c|}
\hline Alkaloid & AChE & BuChE & Reference \\
\hline \multicolumn{4}{|l|}{ Lycorine-Type } \\
\hline Anhydrolycorine (1) & $-8.38^{\mathrm{a}} ;-8.35^{\mathrm{c}}$ & $-8.14^{b}$ & [25] \\
\hline 1-O-Acetylcaranine (2) & $-9.55^{\mathrm{a}}$ & $-8.78^{\mathrm{b}}$ & Calculated values \\
\hline 11,12-Dehydroanhydrolycorine (3) & $-8.41^{\mathrm{a}}$ & $-7.44^{\mathrm{b}}$ & [17] \\
\hline Galanthine (4) & $-8.43^{\mathrm{a}}$ & $-8.37^{b}$ & Calculated values \\
\hline 1-O-Acetyllycorine (5) & $-8.82^{\mathrm{a}}$ & $-9.02^{b}$ & Calculated values \\
\hline Dihydrolycorine (6) & $-8.76^{\mathrm{a}} ;-9.07^{\mathrm{c}}$ & $-8.80^{b}$ & [25] \\
\hline Lycorine (7) & $-8.82^{a}$ & $-8.94^{b}$ & {$[17]$} \\
\hline Sternbergine (8) & $-8.61^{a}$ & $-8.71^{b}$ & Calculated values \\
\hline 2-Methoxypratosine (9) & $-8.14^{\mathrm{a}}$ & $-7.81^{\mathrm{b}}$ & Calculated values \\
\hline \multicolumn{4}{|l|}{ Homolycorine-type } \\
\hline \multicolumn{4}{|l|}{ Crinine/haemanthamine-type } \\
\hline 8-O-Demethylmaritidine (10) & $-8.74^{\mathrm{a}}$ & $-8.93^{b}$ & [17] \\
\hline Cantabricine (11) & $-9.15^{a}$ & $-9.07^{\mathrm{b}}$ & Calculated values \\
\hline Haemanthamine (12) & $-8.80^{\text {a }}$ & $-8.34^{b}$ & [17] \\
\hline \multicolumn{4}{|l|}{ Galanthamine-type } \\
\hline Galanthamine (13) & $-10.10^{a}$ & $-8.23^{b}$ & Calculated values \\
\hline Sanguinine (14) & $-9.40^{\mathrm{a}}$ & $-7.92^{b}$ & {$[25]$} \\
\hline $\mathrm{N}$-Demethylgalanthamine (15) & $-9.09^{a}$ & $-8.81^{b}$ & Calculated values \\
\hline $\mathrm{N}$-Formylnorgalanthamine (16) & $-8.72^{\text {a }}$ & $-8.12^{b}$ & Calculated values \\
\hline \multicolumn{4}{|l|}{ Mesembranone-type } \\
\hline 6-Epimesembranol (17) & $-8.15^{a}$ & $-7.59^{b}$ & Calculated values \\
\hline Mesembrine (18) & $-8.77^{a}$ & $-8.14^{\mathrm{b}}$ & Calculated values \\
\hline \multicolumn{4}{|l|}{ Montanine-type } \\
\hline Pancratinine C (19) & $-8.53^{a}$ & $-8.12^{b}$ & Calculated values \\
\hline
\end{tabular}

a PDB code: $1 D X 6 ;^{\text {b }}$ PDB code: $4 \mathrm{BDS} ;{ }^{\mathrm{c}}$ PDB code: $4 \mathrm{EY7}$.

No alkaloid identified in the samples presented better theoretical AChE inhibitory activity than galanthamine (13). The structures 1-O-acetylcaranine (2) and cantabricine (11) showed high theoretical inhibitory activity against AChE on the 1DX6 structure. The former (2) had two strong interactions (hydrogen bonds), with Ser200 at 2.06 and His440 at $2.16 \AA$ (Figure 5a). In a previous in silico study, isoreticulinine-another lycorine-type alkaloid - was identified as a potential cholinesterase inhibitory molecule based on its interaction with the active site of TcAChE and $\mathrm{hBuChE}$ through strong hydrogen 
bonds in both evaluated proteins [26]. It was not possible to verify interactions between cantabricine (11) and Ser200, although the cantabricine (11)-TcAChE system seems to be stable due to two additional interactions (hydrogen bonds) between this alkaloid and Asp72 at 1.75, and Phe288 at 2.09 A (Figure 5b).

(a)

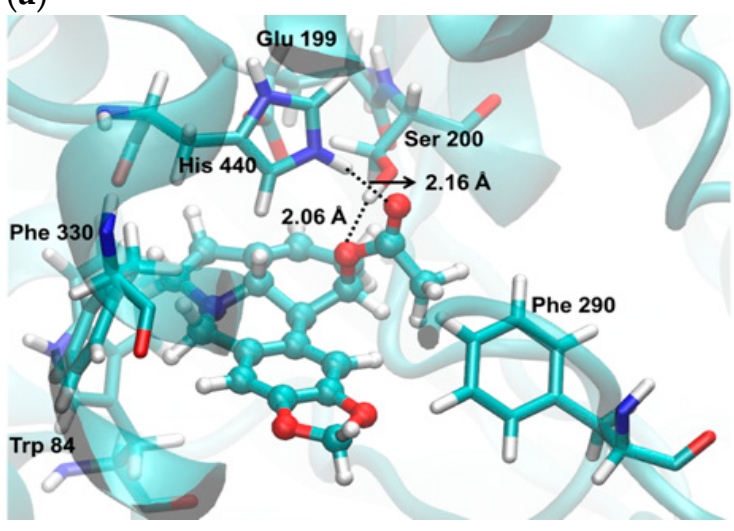

(b)

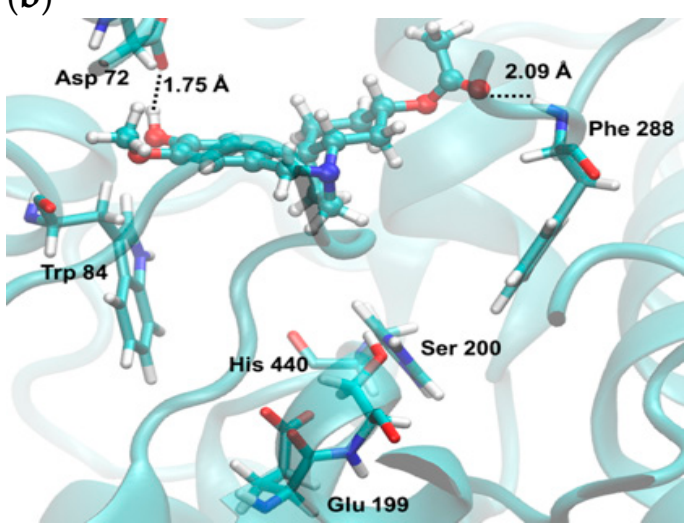

Figure 5. Graphical representations of the binding of (a) 1-O-acetylcaranine (2) and (b) cantabricine (11) in the gorge of the active site of TcAChE.

Molecular simulation of ten alkaloids identified in Phaedranassa species on the 4BDS structure theoretically showed higher enzymatic inhibition than galanthamine (13) against BuChE. They were 1-O-acetylcaranine (2), galanthine (4), 1-O-acetyllycorine (5), dihydrolycorine (6), lycorine (7), sternbergine (8), 8-O-demethylmaritidine (10), cantabricine (11), haemanthamine (12), and $\mathrm{N}$-demethylgalanthamine (15). Among them, 1-O-acetyllycorine (5) and cantabricine (11) presented the best estimated binding free energy toward the active site of $\mathrm{BuChE}$, with a theoretical increase of 0.79 and $0.84 \mathrm{kcal} \cdot \mathrm{mol}^{-1}$, respectively, compared to galanthamine values. In a recent publication, we also observed that in silico deacetylcantabricine, which has a similar structure to cantabricine (11), showed $0.20 \mathrm{kcal} \cdot \mathrm{mol}^{-1}$ greater butyrylcholinesterase inhibition on the 4BDS structure compared to galanthamine [17].

The most important molecular interactions of 1-O-acetyllycorine (5) and cantabricine (11) in the gorge of the active site of $\mathrm{hBuChE}$ are represented in Figure $6 \mathrm{a}, \mathrm{b}$, respectively. The structure of 1-O-acetyllycorine (5) is stabilized by one $\pi-\pi$ stacking interaction with the Trp 82 and two hydrogen bridge interactions with Gly121 and His438. In the case of cantabricine (11), the stabilization is due to the presence of two $\pi-\pi$ stacking interactions with His438 and Trip82. Finally, the molecular docking experiments showed that both alkaloids are close to the catalytic triad of Ser198, Glu325, and His438.

(a)

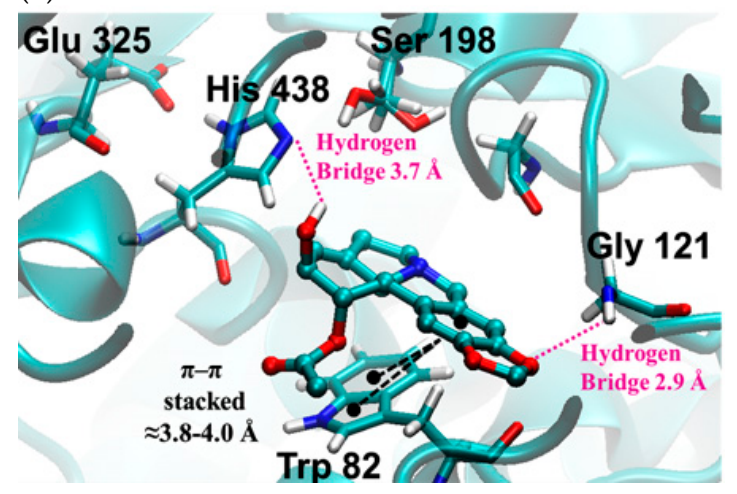

(b)

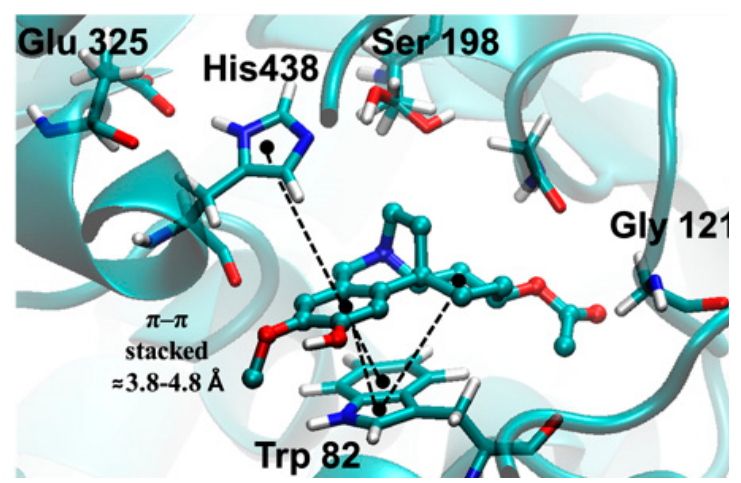

Figure 6. Graphical representations of the binding of (a) 1-O-acetyllycorine (5) and (b) cantabricine (11) in the gorge of the active site of $\mathrm{hBuChE}$. 
The theoretical experiments indicated that cantabricine (11) could be an interesting molecule against both cholinesterases in silico. However, this compound was not detected in P. cuencana (sample B) and P. dubia (sample C) extracts, which exhibited the best inhibitory activity against $\mathrm{AChE}$ and BuChE in vitro. Thus, the high activity of both samples (B and C) could be explained by the presence of galanthamine-type alkaloids, galanthamine (13), and N-demethylgalanthamine (15), with high binding free energy toward the $\mathrm{AChE}$ and $\mathrm{BuChE}$ cholinesterases (see Table 2). The presence of two alkaloids with a high-energy ligand-protein interaction indicates that the in vitro results could have been enhanced by a synergistic mechanism [25]. The species P. tunguraguae (sample E), which does not contain galanthamine-type alkaloids, also presented an AChE and BuChE inhibitory effect in vitro. According to the molecular docking experiments, the presence of cantabricine (11) in this sample could have contributed to these results.

\section{Materials and Methods}

\subsection{Plant Material}

Bulbs of five different Phaedranassa species were collected in Ecuador in 2017 and 2018. Phaedranassa cinerea (Chimborazo, Pallatanga, Ecuador), Phaedranassa cuencana (Azuay, Sevilla de Oro, Ecuador), Phaedranassa dubia (Pichincha, Pululahua, Ecuador), Phaedranassa glauciflora (Chimborazo, Alausí, Ecuador), and Phaedranassa tunguraguae (Tungurahua, Baños, Ecuador) (Figure 1). Samples were identified by the group specialist, Dra. Nora Oleas. Herbarium specimen vouchers are $P$. cinerea (Øllgaard and Balslev 9006), P. cuencana (Oleas 1031, HUTI), P. dubia (Oleas 4, QCA), P. glauciflora (Oleas 44, QCA), and P. tunguraguae (Oleas 6, QCA).

\subsection{Extractions}

Fresh bulbs of Phaedranassa were collected, cleaned, and dried for 7 days at $40{ }^{\circ} \mathrm{C}$. About $2 \mathrm{~g}$ of each sample was macerated with $\mathrm{MeOH}(3 \times 100 \mathrm{~mL})$ at room temperature for 3 days. The organic solvent was taken to dryness under reduced pressure to afford the crude extracts, which were acidified to $\mathrm{pH} 3$ with diluted $\mathrm{H}_{2} \mathrm{SO}_{4}(2 \%, v / v)$, and the neutral material was removed with $\mathrm{Et}_{2} \mathrm{O}$. The aqueous solutions were basified up to $\mathrm{pH} 10$ with $\mathrm{NH}_{4} \mathrm{OH}(25 \%, v / v)$ and extracted with EtOAc to obtain the alkaloid extracts (AE), which were used in the experiments.

\subsection{Acetylcholinesterase (AChE) and Butyrylcholinesterase (BuChE) Inhibitory Activity}

Cholinesterase inhibitory activity was determined according to [27] with some modifications [28]. Stock solutions with 518U of AChE from Electrophorus electricus (Merck, Darmstadt, Germany) and BuChE from equine serum (Merck, Darmstadt, Germany), respectively, were prepared and kept at $-20^{\circ} \mathrm{C}$. Acetylthiocholine iodide (ATCI), S-butyrylthiocholine iodide (BTCI), and 5,5'-dithiobis (2-nitrobenzoic) acid (DTNB) were obtained from Merck (Darmstadt, Germany). Fifty microliters of $\mathrm{AChE}$ or BuChE (both enzymes used at $6.24 \mathrm{U})$ in phosphate buffer $\left(8 \mathrm{mM} \mathrm{K}_{2} \mathrm{HPO}_{4}, 2.3 \mathrm{mM} \mathrm{NaH}_{2} \mathrm{PO}_{4}\right.$, $0.15 \mathrm{NaCl}, \mathrm{pH} 7.5)$ and $50 \mu \mathrm{L}$ of the sample dissolved in the same buffer were added to the wells. The plates were incubated for $30 \mathrm{~min}$ at room temperature. Then, $100 \mu \mathrm{L}$ of the substrate solution (0.1 $\mathrm{M} \mathrm{Na}_{2} \mathrm{HPO}_{4}, 0.5 \mathrm{M}$ DTNB, and $0.6 \mathrm{mM}$ ATCI or $0.24 \mathrm{mM}$ BTCI in Millipore water, $\left.\mathrm{pH} 7.5\right)$ was added. These reagents were obtained from Merck (Darmstadt, Germany). After 10 min, the absorbance was read at $405 \mathrm{~nm}$ in a Labsystem microplate reader (Helsinki, Finland). Enzyme activity was calculated as percent compared to a control using a buffer without any inhibitor. Galanthamine served as a positive control. In a first step, activity of samples was assessed at 10, 100, and $200 \mu \mathrm{g} \cdot \mathrm{mL}^{-1}$ towards both enzymes. Samples with an $\mathrm{IC}_{50}>200 \mu \mathrm{g} \cdot \mathrm{mL}^{-1}$ were considered inactive. Samples with an $\mathrm{IC}_{50}<200 \mu \mathrm{g} \cdot \mathrm{mL}^{-1}$ were further analyzed to determine the $\mathrm{IC}_{50}$ values. The cholinesterase inhibitory data were analyzed with the Microsoft Office Excel 2010 software. 


\subsection{Alkaloid Identification and Quantification}

Alkaloid profiles of the Phaedranassa samples were obtained using GC-MS (Agilent Technologies $6890 \mathrm{~N}$ coupled with MSD5975 inert XL; Santa Clara, CA, USA) equipment operating in electron ionization (EI) mode at $70 \mathrm{eV}$. A Sapiens-X5 MS column $(30 \mathrm{~m} \times 0.25 \mathrm{~mm}$ i.d., film thickness $0.25 \mu \mathrm{m}$; Teknokroma, Barcelona, Spain) was used. The temperature gradient was $12 \mathrm{~min}$ at $100{ }^{\circ} \mathrm{C}, 100-180{ }^{\circ} \mathrm{C}$ at $15{ }^{\circ} \mathrm{C} \cdot \mathrm{min}^{-1}, 180-300{ }^{\circ} \mathrm{C}$ at $5{ }^{\circ} \mathrm{C} \cdot \mathrm{min}^{-1}$, and $10 \mathrm{~min}$ hold at $300{ }^{\circ} \mathrm{C}$. The injector and detector temperatures were 250 and $280^{\circ} \mathrm{C}$, respectively, and the flow-rate of carrier gas (He) was $1 \mathrm{~mL} \cdot \mathrm{min}^{-1}$. A total of $2 \mathrm{mg}$ of each alkaloid extract was dissolved in $1 \mathrm{~mL}$ of $\mathrm{MeOH}: \mathrm{CHCl}_{3}(1: 1, v / v)$, and $1 \mu \mathrm{L}$ of each sample was injected in the equipment using the splitless mode. Codeine $\left(0.05 \mathrm{mg} \cdot \mathrm{mL}^{-1}\right)$ was used as the internal standard. Alkaloids were identified by GC-MS and the mass spectra were deconvoluted using the software AMDIS 2.64. Kovats retention indexes (RI) were recorded with a standard calibration n-hydrocarbon mixture (C9-C36) using AMDIS 2.64 software.

A calibration curve of galanthamine $\left(10,20,40,60,80\right.$, and $\left.100 \mu \mathrm{g} \cdot \mathrm{mL}^{-1}\right)$ was applied to quantify each single constituent detected in the chromatogram, using codeine $\left(0.05 \mathrm{mg} \cdot \mathrm{mL}^{-1}\right)$ as the internal standard. Peak areas were manually obtained, considering selected ions for each compound (usually the base peak of their MS, i.e., $\mathrm{m} / \mathrm{z}$ at 286 for galanthamine and 299 for codeine). The ratio between the values obtained for galanthamine and codeine in each solution was plotted against the corresponding concentration of galanthamine to obtain the calibration curve and its equation $(y=0.0112 x-0.0469$; $\left.R^{2}=0.9995\right)$. All data were standardized to the area of the internal standard (codeine), and the equation obtained for the calibration curve of galanthamine was used to calculate the amount of each alkaloid. Results are presented as mg GAL (galanthamine), which was finally related to the alkaloid extract (AE). As the peak area does not only depend on the corresponding alkaloid concentration but also on the intensity of the mass spectra fragmentation, the quantification is not absolute. However, the method is considered suitable to compare the specific alkaloid amount between samples $[16,17,29]$.

\subsection{Statistical Analysis}

Three independent assays were used to evaluate the cholinesterase activity of Phaedranassa samples. Results were analyzed by ANOVA, using the PRISM software. Data are expressed as the mean \pm standard deviation (SD). Significant results are marked as follows: ${ }^{* * * *} p<0.0001,{ }^{* * *} p<0.001,{ }^{*} p<0.5$, and $n s$ (not significant). One-way ANOVA with Dunnet's multiple comparison test was used and the differences are with respect to the results of galanthamine with both enzymes.

\subsection{Molecular Docking}

Molecular docking simulations for the principal alkaloids identified from Phaedranassa species were performed to investigate the binding mode into the active site of two different enzymes, Torpedo californica AChE (TcAChE) and human BuChE (hBuChE), PDB codes 1DX6 [30] and 4BDS [31]. Three-dimensional (3D) structures of the alkaloids were recovered from the PubChem database and submitted to a geometrical optimization procedure at PBE0 [32,33]/6-311 + $\mathrm{g}^{*}$ [34] level of theory using the program Gaussian 09 [35]. All optimized alkaloids were confirmed as a minimum on the potential energy surface.

Docking simulations for the set of optimized ligands were performed using the AutoDock v.4.2 program (Molecular Graphics Laboratory, La Jolla, CA, USA) [36]. AutoDock uses a rapid energy evaluation in precalculated grids of affinity potentials and several search algorithms to identify suitable binding positions for a ligand on a given macromolecule. In order to compare the results from the docking simulations, water molecules, cofactors, and ions were excluded from each $x$-ray crystallographic structure. Likewise, polar hydrogen atoms of the enzymes were added and nonpolar hydrogen atoms were merged. Finally, the enzyme was treated as a rigid body. Grid maps of interaction energy for various atom types with each macromolecule were calculated by the auxiliary program AutoGrid (Molecular Graphics Laboratory, La Jolla, CA, USA) using a grid box with dimensions of 
$60 \times 60 \times 60 \AA$ around the active site, which was large enough to include the most important residues of each enzyme. Docking searches for the best orientations of the ligands binding to the active site of each protein were performed using the Lamarckian Genetic Algorithm (LGA) [37]. The LGA protocol applied a population size of 2000 individuals, while 2,500,000 energy evaluations were used for the 50 LGA runs. The best conformations were chosen from the lowest docked energy solutions in the cluster populated by the highest number of conformations. Finally, best docking complex solutions (poses) were analyzed according to the potential intermolecular interactions (ligand/enzyme), such as hydrogen bonding and the cation $-\pi, \pi-\pi$ stacking.

\section{Conclusions}

In summary, thirty-three compounds were detected, and nineteen known alkaloids were identified by GC-MS in five different species of Phaedranassa Herb. from Ecuador. Galanthamine-type alkaloids were detected in all the samples, with the highest concentration in P. cuencana. Extracts from all the species showed activity against $\mathrm{AChE}$ and BuChE. In vitro, P. cuencana and P. dubia proved to be the most active against $\mathrm{AChE}$ and $\mathrm{BuChE}$, respectively, whereas in silico results indicated that cantabricine is highly inhibitory against both cholinesterases. This study, which is the first to report the alkaloid profile and biological activities of P. cuencana, P. glauciflora, and P. tunguraguae, supports the role of Amaryllidaceae species as a source of alkaloids with potential application for the palliative treatment of AD.

Author Contributions: L.R.T. and R.M. performed the experiments, analyzed the data, and wrote the paper. C.S. and E.M. performed experiments. E.H.O. performed the molecular docking experiment and wrote the paper. J.B. designed the experiments, analyzed the data, and wrote the paper. N.H.O. collected plants and wrote the paper. K.A.L. analyzed the data, collected plants, and wrote the paper. All authors have read and agreed to the published version of the manuscript.

Funding: This research was funded by Programa CYTED, grant number, 416RT0511 and Universidad Tecnológica Indoamérica, grant number Biocamb-02-(2016-2020).

Acknowledgments: The authors (Research Group 2017-SGR-604 from University of Barcelona) thank CCiTUB for technical support. LRT is thankful to CAPES (Coordenação de Pessoal de Nivel Superior-Bolsista CAPES, Processo 13553135) for a doctoral and postdoctoral fellowship. KA, CS, EM gratefully acknowledge Escuela Superior Politécnica del Chimborazo for the purchase of equipment. KA thank Diego Vinueza, Viviana Baldeón and Tatiana Jaramillo for their technical assistance. The authors thank to the Ministerio del Ambiente of Ecuador for collecting permits MAE-DNB-CM-2015-0054 and MAE-DNB-CM-2018-0086. The authors thank to Centro de Investigación para el Territorio y Hábitat Sostenible (CITEHS) for help with Figure 1.

Conflicts of Interest: The authors declare no conflict of interest.

\section{References}

1. Newman, D.J.; Cragg, G.M. Natural products as sources of new drugs from 1981 to 2014. J. Nat. Prod. 2016, 79, 629-661. [CrossRef] [PubMed]

2. Harvey, A. Strategies for discovering drugs from previously unexplored natural products. Drug Discov. Today 2000, 5, 294-300. [CrossRef]

3. Rodrigues, T.; Reker, D.; Schneider, P.; Schneider, G. Counting on natural products for drug design. Nat. Chem. 2016, 8, 531-541. [CrossRef] [PubMed]

4. Stratton, C.F.; Newman, D.J.; Tan, D.S. Cheminformatic comparison of approved drugs from natural products versus synthetic origins. Bioorg. Med. Chem. Lett. 2015, 25, 4802-4807. [CrossRef]

5. Bastida, J.; Lavilla, R.; Viladomat, F. Chemical and biological aspects of Narcissus Alkaloids. In The Alkaloids: Chemistry and Physiology; Cordell, G.A., Ed.; Elsevier: Amsterdam, The Netherlands, 2006; Volume 63, pp. 87-179. [CrossRef]

6. Minga, D.; Ulloa, C.U.; Oleas, N.; Verdugo, A. A new species of Phaedranassa (Amaryllidaceae) from Ecuador. Phytotaxa 2015, 192, 50-53. [CrossRef]

7. Oleas, N. Landscape Genetics of Phaedranassa Herb. (Amaryllidaceae) in Ecuador. Ph.D. Thesis, Florida International University, Miami, FL, USA, 2011. 
8. Oleas, N. Amaryllidaceae. In Libro Rojo de Plantas Endémicas del Ecuador; León-Yánez, S., Valencia, R., Pitman, N., Endara, L., Ulloa Ulloa, C., Navarrete, H., Eds.; Publicaciones del Herbario QCA, Pontificia Universidad Católica del Ecuador: Quito, Ecuador, 2011.

9. Oleas, N.H.; Meerow, A.W.; Francisco-Ortega, J. Population dynamics of the endangered plant, Phaedranassa tunguraguae, from the Tropical Andean Hotspot. J. Hered 2012, 103, 557-569. [CrossRef]

10. Oleas, N.H.; Meerow, A.W.; Francisco-Ortega, J. Genetic structure of the threatened Phaedranassa schizantha (Amaryllidaceae). Bot. J. Linn. Soc. 2016, 182, 169-179. [CrossRef]

11. Alzheimer's Disease International. 2018. Available online: https://www.alz.co.uk/research/WorldAlzheimer Report2018.pdf (accessed on 30 January 2020).

12. Selkoe, D.J. Alzheimer's Disease: Genes, proteins, and therapy. Physiol. Rev. 2001, 81, 741-766. [CrossRef]

13. Konrath, E.L.; dos Santos Passos, C.; Klein-Júnior, L.C.; Henriques, A.T. Alkaloids as a source of potential anticholinesterase inhibitors for the treatment of Alzheimer's disease. J. Pharm. Pharm. 2013, 65, 1701-1725. [CrossRef]

14. Maelicke, A.; Samachocki, M.; Jostock, R.; Fehrenbacher, A.; Ludwig, J.; Albuquerque, E.X.; Zerlin, M. Allosteric sensitization of nicotine receptors by galanthamine, a new treatment strategy for Alzheimer's disease. Biol. Psychiatry 2001, 49, 279-288. [CrossRef]

15. Torras-Claveria, L.; Tallini, L.; Viladomat, F.; Bastida, J. Research in natural products: Amaryllidaceae ornamental plants as sources of bioactive compounds. In Recent Advances in Pharmaceutical Sciences VII; Muñoz-Torrero, D., Riu, M., Feliu, C., Eds.; Research Signpost Trivandrum: Kerala, India, 2017; pp. 69-82. ISBN 978-81-308-0573-3.

16. Guo, Y.; Pigni, N.B.; Zheng, Y.; de Andrade, J.P.; Torras-Claveria, L.; Borges, W.S.; Viladomat, F.; Codina, C.; Bastida, J. Analysis of bioactive Amaryllidaceae alkaloid profiles in Lycoris species by GC-MS. Nat. Prod. Commun. 2014, 9, 1081-1086. [CrossRef] [PubMed]

17. Tallini, L.R.; Bastida, J.; Cortes, N.; Osorio, E.H.; Theoduloz, C.; Schemeda-Hirschmann, G. Cholinesterase inhibition activity, alkaloid profiling and molecular docking of Chilean Rhodophiala (Amaryllidaceae). Molecules 2018, 23, 1532. [CrossRef] [PubMed]

18. Osorio, E.J.; Berkov, S.; Brun, R.; Codina, C.; Viladomat, F.; Cabezas, F.; Bastida, J. In vitro antiprotozoal activity of alkaloids from Phaedranassa dubia (Amaryllidaceae). Phytochem. Lett. 2010, 3, 161-163. [CrossRef]

19. Acosta, K.; Pigni, N.; Oleas, N.; Bastida, J. Identification of the alkaloids of Stenomesson aurantiacum (Kunth) Herb., an Amaryllidaceae species from the Ecuadorian Andes. Pharmacol. Online 2014, 3, 178-183.

20. Berkov, S.; Georgieva, L.; Kondakova, V.; Atanassov, A.; Viladomat, F.; Bastida, J.; Codina, C. Plant sources of galanthamine: Phytochemical and biotechnological aspects. Biotechnol. Biotechnol. Equip. 2009, 23, 1170-1176. [CrossRef]

21. Bores, G.M.; Huger, F.P.; Petko, W.; Mutlib, A.E.; Camacho, F.; Rush, D.K.; Selk, D.E.; Wolf, V.; Kosley, R.W., Jr.; Davis, L.; et al. Pharmaceutical evaluation of novel Alzheimer's disease therapeutics: Acetylcholinesterase inhibitors related to galanthamine. J. Pharm. Exp. 1996, 277, 728-738.

22. Iannello, C.; Pigni, N.B.; Antognoni, F.; Poli, F.; Maxia, A.; de Andrade, J.P.; Bastida, J. A potent acetylcholinesterase inhibitor from Pancratium illyricum L. Fitoterapia 2014, 92, 163-167. [CrossRef]

23. Sussman, J.L.; Harel, M.; Frolow, F.; Oefner, C.; Goldman, A.; Toker, L.; Silman, I. Atomic structure of acetylcholinesterase from Torpedo californica: A prototypic acetylcholine-binding protein. Science 1991, 253, 872-879. [CrossRef]

24. Nicolet, Y. Crystal structure of human butyrylcholinesterase and of its complexes with substrate and products. J. Biol. Chem. 2003, 278, 41141-41147. [CrossRef]

25. Cortes, N.; Sierra, K.; Alzate, F.; Osorio, E.H.; Osorio, E. Alkaloids of Amaryllidaceae as inhibitors of cholinesterases (AChEs and BuChEs): An integrated bioguided study. Phytochem. Anal. 2018, 29, $217-227$. [CrossRef]

26. Tallini, L.R.; Osorio, E.H.; dos Santos, V.D.; De Souza Borges, W.; Kaiser, M.; Viladomat, F.; Zuanazzi, J.A.S.; Bastida, J. Hippeastrum reticulatum (Amaryllidaceae): Alkaloid, profiling, biological activities and molecular docking. Molecules 2017, 22, 2191. [CrossRef] [PubMed]

27. Ellman, G.L.; Courtney, K.D.; Andres Jr., V.; Featherstone, R.M. A new and rapid colorimetric determination of acetylcholinesterase activity. Biochem. Pharm. 1961, 7, 88-95. [CrossRef]

28. López, S.; Bastida, J.; Viladomat, F.; Codina, C. Acetylcholinesterase inhibitory activity of some Amaryllidaceae alkaloids and Narcissus extracts. Life Sci. 2002, 71, 2521-2529. [CrossRef] 
29. Torras-Claveria, L.; Berkov, S.; Codina, C.; Viladomat, F.; Bastida, J. Metabolomic analysis of bioactive Amaryllidaceae alkaloids of ornamental varieties of Narcissus by GC-MS combined with k-means cluster analysis. Ind. Crop. Prod. 2014, 56, 211-222. [CrossRef]

30. Greenblatt, H.M.; Kryger, G.; Lewis, T.; Silman, I.; Sussman, J.L. Structure of acetylcholinesterase complexed with (-)-galanthamine at $2.3 \AA$ resolution. Febs Lett. 1999, 463, 321-326. [CrossRef]

31. Nachon, F.; Carletti, E.; Ronco, C.; Trovaslet, M.; Nicolet, Y.; Jean, L.; Renard, P.-Y. Crystal structures of human cholinesterases in complex with huprine $\mathrm{W}$ and tacrine: Elements of specificity for anti-Alzheimer's drugs targeting acetyl- and butyryl-cholinesterase. Biochem. J. 2013, 453, 393-399. [CrossRef]

32. Adamo, C.; Barone, V. Toward reliable density functional methods without adjustable parameters: The PBE0 model. J. Chem. Phys. 1999, 110, 6158-6170. [CrossRef]

33. Ernzerhof, M.; Scuseria, G.E. Assessment of the Perdew-Burke- Ernzerhof exchange-correlation functional. J. Chem. Phys. 1999, 110, 5029-5036. [CrossRef]

34. Petersson, G.A.; Bennett, A.; Tensfeldt, T.G.; Al-Laham, M.A.; Shirley, W.A.; Mantzaris, J.; Mantzaris, J. A complete basis set model chemistry. I. The total energies of closed-shell atoms and hydrides of the first-row elements. J. Chem. Phys. 1988, 89, 2193-2218. [CrossRef]

35. Frisch, M.J.; Trucks, G.W.; Schlegel, H.B.; Scuseria, G.E.; Robb, M.A.; Cheeseman, J.R.; Scalmani, G.; Barone, V.; Mennucci, B.; Petersson, G.A.; et al. Gaussian 09, Revis. E.01; Gaussian, Inc.: Wallingford, CT, USA, 2013.

36. Moris, G.M.; Huey, R.; Lindstrom, W.; Sanner, M.F.; Belew, R.K.; Goodsell, D.S.; Olson, A.J. Autodock4 and AutoDockTools4: Automated docking with selective receptor flexibility. J. Comput. Chem. 2009, 16, 2785-2791. [CrossRef]

37. Thomsen, R.; Christensen, M.H. MolDock: A new technique for high-accuracy molecular docking. J. Med. Chem. 2006, 49, 3315-3321. [CrossRef] [PubMed]

Sample Availability: Samples of the compounds are not available from the authors.

(C) 2020 by the authors. Licensee MDPI, Basel, Switzerland. This article is an open access article distributed under the terms and conditions of the Creative Commons Attribution (CC BY) license (http://creativecommons.org/licenses/by/4.0/). 